Article

\title{
Root Traits Determine Variation in Nonstructural Carbohydrates (NSCs) under Different Drought Intensities and Soil Substrates in Three Temperate Tree Species
}

\author{
Li Ji ${ }^{1,2}$, Khan Attaullah ${ }^{2}$, Jun Wang ${ }^{1}$, Dapao Yu ${ }^{3}{ }^{-}$, Yuchun Yang ${ }^{1, *}$, Lixue Yang ${ }^{2}$ and \\ Zhimin Lu ${ }^{1}$ \\ 1 Jilin Academy of Forestry, Changchun 130033, China; jlnefu@hotmail.com (L.J.); \\ wangjun3528@126.com (J.W.); Luzhimin402@sohu.com (Z.L.) \\ 2 Key Laboratory of Sustainable Forest Ecosystem Management-Ministry of Education, School of Forestry, \\ Northeast Forestry University, Harbin 150040, China; khan.aup252@gmail.com (K.A.); \\ ylx_0813@163.com (L.Y.) \\ 3 Key Laboratory of Forest Ecology and Management, Institute of Applied Ecology, Chinese Academy of \\ Sciences, Shenyang 110016, China; yudp2003@iae.ac.cn \\ * Correspondence: yang-yu-chun@163.com; Tel.: +86-0431-8585-0434
}

Received: 20 March 2020; Accepted: 4 April 2020; Published: 8 April 2020

check for updates

\begin{abstract}
Nonstructural carbohydrates (NSCs) are a key factor in the physiological regulation of plants and can reflect buffering capacity of plants under diverse environmental conditions. The effects of diverse environmental conditions on plant NSCs and tissue or organ scales have been thoroughly studied, but their effects on fine root (root diameter $<2 \mathrm{~mm}$ ) NSC concentrations are still not completely understood. Our aims were to explore the synergistic fluctuations in root traits and NSC concentrations under diverse environmental conditions. This study was conducted on two-year-old temperate seedling tree species (Juglans mandshurica Maxim., Fraxinus mandshurica Rupr., and Phellodendron amurense Rupr.) with different drought intensities and soil substrates. The specific root length (SRL) and specific root surface area (SRA) were significantly affected by drought intensities and soil substrates, while the root tissue density (RTD) and average diameter (AD) were not significantly affected by water intensities and soil substrates in all three species. The $\operatorname{root} C, N$, and $\mathrm{P}$ concentration did not change according to drought stress but were significantly affected by the soil substrates in all three species. Similarly, the soluble sugar (SS) and starch (ST) concentrations were significantly affected by both the drought stress and the soil substrates in all three species. The AD explained $6.8 \%$ of the total variations in soluble sugar, while the SRL explains $32.1 \%$ of the total variation in starch. The root tip C, N, and P concentrations were not significantly correlated with NSCs under different treatments. The total variations in root tip morphology, chemistry, and NSC concentrations are greater among species than compared to different drought intensities and soil substrates. However, the root NSC concentrations were closely related to root morphological traits (SRL and AD) rather than chemical traits. On the basis of different soil resources, the species with thinner diameters have higher SS concentrations, while those of a thicker diameter have higher ST concentrations.
\end{abstract}

Keywords: root tip; nonstructural carbohydrates; morphological traits; drought; soil substrates

\section{Introduction}

Variations in climatic conditions, high temperatures, and low rainfall have caused most parts of the world to become dry, especially in temperate regions, resulting in tree death and forest ecosystem 
declines [1-3]. The IPCC (Intergovernmental Panel on Climate Change) predicted that the most serious and frequent drought events will occur in the coming decades [4]. Nonstructural carbohydrates (NSCs, mainly composed of soluble sugar and starch) are a product of plant photosynthesis and the main substrate for plant respiration, which is responsible for the carbon budget balance $[5,6]$. NSC also reflects the level of substance for plant survival, growth, and their buffering capacity under environmental degradation [7] and NSCs are an important factor in the regulation of plant physiological phenomena under diverse environmental conditions. In recent years, most of the studies examining NSC dynamics at the tissue or organ scale have investigated the effects of water [1,8-10], $\mathrm{CO}_{2}$ concentrations [11], shade [10,12], and other factors. However, these studies have rarely focused on root traits, especially the root tip morphology under different drought intensities. Some recent studies have documented that root tissue has the highest NSC concentrations, which can affect NSC storage and distribution in trees, but not in tree trunks $[13,14]$. Therefore, exploring the variation in the composition and distribution of fine roots under drought is important for better understanding how carbon balance and dynamics affect plant growth and survival [15].

Fine roots (root diameter $<2 \mathrm{~mm}$ ) are the most important organs of plants and are used for water and nutrient uptake from soil. Moreover, their growth characteristics and conditions can directly affect the growth and development of individual plants. Carbohydrates in roots are mainly used for physiological activities, such as plant growth, respiration rate, nutrient absorption, and organic secretion [16]. Carbohydrate storage in plants can play an important role in plant metabolism, defense, and drought resistance, delaying or preventing plant death. Pregitzer et al. [17] found significant differences in the root morphology (such as diameter) and tissue nitrogen $(\mathrm{N})$ content of the fine roots among nine North American tree species. In recent years, many researchers have observed that lower root order diameters (especially root tips) of plants that have a higher turnover rate, a shorter lifespan, a stronger absorption capacity for water and nutrients, and are more sensitive to diverse environmental conditions [18,19]. A subsequent study by Hartmann [8] found that drought stress can cause a decrease in NSC content in forest roots. However, we have little knowledge about the changes in the composition and level of NSCs in plant root tip tissue (first-order roots) under drought conditions. Several studies have found that there are large intra- and interspecific [20-22] variations in fine root diameter, especially in tropical species [23]. These differences in root diameter directly lead to changes in the absorption capacity, root lifespan, and turnover rate under different resource conditions [24]. Therefore, plant functional traits can be adjusted according to their environment, which could allow the same species to grow and survive under diverse environmental conditions [25]. By comparing the different root-order traits of different diameters of beech and Norway spruce, Weemstra et al. [26] found that tree species in poor soil changed their root architecture rather than their morphological traits; the authors also observed interspecies differences in plasticity reactions. The leaf intra- and interspecific plasticity for environmental resource availability has been widely reported [27,28], while only a the few studies were found on roots [29]. The response strategies of fine root of different species under different soil resources and drought intensities are especially scarce in the literature.

Juglans mandshurica Maxim. (JM), Fraxinus mandshurica Rupr. (FM), and Phellodendron amurense Rupr. (PA), known as the three most valuable hardwood trees, are important dominant species in broadleaf Korean pine forests in Northeast China [30]. However, the decline of these species in secondary forests is very common due to diverse environmental conditions [30,31]. Understanding the physiological and ecological phenomena of these tree species under diverse environmental conditions is important and could contribute to better forest management practices to successfully promote the succession of these species [32]. These species were also observed to have relatively large compound leaves with a fine root diameter gradient. Compound leaves are derived features in angiosperms that can develop independently in multiple lineages $[33,34]$. These species often appear in warm and water-restricted (arid or semi-arid) areas, indicating their ability to adapt to diverse environmental conditions [35]. It has also been observed that compound leaf species are more likely to be pioneers and early succession species [36,37]. They can produce relatively larger and cheaper petioles and grow 
rapidly under favorable environmental conditions [38]. Conversely, they can also adapt to seasonal and unpredictable drought stress and can minimize their water loss by reducing their leaf size under drought conditions, thereby better protecting stems with a greater carbon cost from catastrophic hydraulic failure and withering than would be the case for typical hydraulic segmentation behavior [39,40]. However, the interspecific variation of fine root NSC levels in compound leaf species under different environmental conditions remains unclear, and the relationship between root morphological traits and NSCs has not been clarified.

Stands of JM, FM, and PA are normally distributed in the north-south latitude in Jilin Province, China. The soils in different areas are roughly divided into three types (humus, loam, and sandy-loam). In our study, these three species of temperate tree seedlings were experimentally grown under different drought intensities and soil substrates according to different soil textures. Our aim was to compare the effects of root tip NSCs with different fine root diameters under drought intensities and soil substrates on temperate tree seedlings. We hypothesized that (1) in mild and moderate drought intensities, the three species would have a higher specific root length (SRL), a higher specific root surface area (SRA), and a thinner average diameter (AD); (2) the root NSC concentrations would be significantly different among the three species, and the thinner root diameter would have a lower SS concentration; (3) the NSC concentrations of the plant tissue are hypothesized to be mainly affected by the carbon absorption and consumption of the plant, therefore the NSC concentrations are significantly correlated with the fine root chemistry.

\section{Materials and Methods}

\subsection{Experimental Site and Sapling Preparation}

A controlled pot experiment was conducted at the Xinli experimental site in Changchun, Jilin Province, China $\left(43^{\circ} 33^{\prime} \mathrm{N}-44^{\circ} 41^{\prime} \mathrm{N}, 125^{\circ} 19^{\prime} \mathrm{E}-125^{\circ} 24^{\prime} \mathrm{E}\right)$. This area has a warm and continental monsoon climate with hot, wet summers and cold, dry winters. The study site has a frost-free period of 140 days and a mean annual rainfall of 600-800 mm, which mainly occurs from July to September; the mean annual temperature is $4.6^{\circ} \mathrm{C}$. The area features a natural distribution of Juglans mandshurica, Fraxinus mandshurica, and Phellodendron amurense.

The seeds of Juglans mandshurica (JM), Fraxinus mandshurica (FM), and Phellodendron amurense (PA) were collected by the Lushuihe Forestry Bureau in Jilin Province in 2015. In 2016, the sterilized and germinated seeds were sown into the nursery (humus soil), and the required amounts of water and fertilizer were applied during the entire growing season. The two-year-old seedlings of JM, FM, and PA were transplanted into brick-red plastic pots $(24 \times 20 \mathrm{~cm})$ in April 2017, and were placed in plastic greenhouse cultivation before starting to bud. At the experimental site, the pots were placed in rows $50 \mathrm{~cm}$ apart from each other under full sunlight. All pots were equally irrigated prior to application of the drought treatments, and the gravimetric soil water content was initially maintained at field capacity. The soil surface was well ventilated throughout the experiment. The pots were filled with cultured soil with equal volumes of humus, loam, and sandy-loam, and the humus was collected in the natural coniferous and broadleaf forest around the experimental site. The soil type was classified according to the Food and Agricultural Organization soil classification system (FAO 1998) as Eum-Orthic Anthrosol.

\subsection{Experimental Design}

Three soil substrate samples were collected in July 2017 for the determination of total nitrogen, total phosphorus, available phosphorus, soil physical properties, water content, and field water holding capacity. The seedlings of JM, FM, and PA (with a uniform size in terms of their height and diameter) in each pot were randomly selected from three soil substrates to carry out the water control experiments. The collar diameter and plant height of each seedling were measured using a Vernier caliper with an accuracy of $0.01 \mathrm{~mm}$ and a measuring tape with an accuracy of $0.1 \mathrm{~cm}$ prior to the application of drought treatments in July 2017 (leaves fully expanded). 
A two-factor complete orthogonal design was conducted with three tree species, three soil substrates, and four drought intensities. Three soil substrates were set with four drought intensities $(80 \%, 60 \%, 40 \%$, and $20 \%)$ for the field water holding capacity (representing a normal water supply CK, mild drought T1, moderate drought T2, and severe drought T3) with a total of 12 treatments (Figure S1). Each treatment consisted of three blocks, and 40 pots per tree species were selected in each block (with a uniform size in terms of their height and diameter). For the water control experiments, the whole pot weighing method was used during the experiment. Based on the previously measured water content and field water holding capacity, the total weight of the soil, pots, and seedlings was calculated under different water conditions, and the pots were weighed every two days using an industrial grade balance with an accuracy of $5 \mathrm{~g}$. Subsequently, each pot was irrigated to maintain the desired pot mass, and this watering regime was continued until the 10 September (abscission period). Since the seedling's own weight was constantly changing during the whole drought regime, the seedling weight was measured again every $20 \mathrm{~d}$ (select five sampling, three times in total until September 10), and the theoretical total weight was corrected before maintaining the desired pot mass.

\subsection{Sampling and Measurements}

\subsubsection{Plant Sample Collection}

In each experimental block, 10 seedlings per treatment were randomly selected, and the root samples were collected after 60 days of continuous drought stress. The root samples were sorted carefully from the soil and washed with tap water to remove soil particles. They were then placed in a labeled pocket and stored $\left(2-3{ }^{\circ} \mathrm{C}\right)$. Then, the root samples were divided into two parts: one for root morphological traits and the other for chemical traits. All root samples were transferred to the laboratory on the same day and stored $\left(-20^{\circ} \mathrm{C}\right)$; the live root samples were then analyzed, and the dead roots were picked and discarded.

\subsubsection{Soil Physical and Chemical Properties}

The physicochemical properties of the three soil substrates were determined before the application of drought stress (Table 1). The soil total nitrogen was determined by Kjeldahl titration. The soil total phosphorus was measured by the sulfuric acid-perchloric acid-molybdenum anti-colorimetric method [41]. Soil available phosphorus was extracted by double acid extraction, and soil water content and bulk density were surveyed by the ring knife method. Methods for the determination of total soil porosity, soil aeration, water absorption multiple, water seepage rate, and evaporation rate were used as previously described [42].

Table 1. Physicochemical properties of three soil substrates.

\begin{tabular}{cccc}
\hline $\begin{array}{c}\text { Soil Substrate } \\
\text { Physicochemical Property }\end{array}$ & Humus & Loam & Sandy-Loam \\
\hline Bulk density $\left(\mathrm{g} \cdot \mathrm{cm}^{-3}\right)$ & $1.18 \pm 0.02 \mathrm{~b}$ & $1.35 \pm 0.02 \mathrm{a}$ & $1.32 \pm 0.02 \mathrm{a}$ \\
Total porosity $(\%)$ & $53.19 \pm 1.12 \mathrm{~b}$ & $58.90 \pm 0.91 \mathrm{a}$ & $36.72 \pm 0.95 \mathrm{c}$ \\
Aeration porosity $(\%)$ & $25.61 \pm 0.48 \mathrm{a}$ & $23.52 \pm 0.53 \mathrm{a}$ & $13.01 \pm 0.99 \mathrm{~b}$ \\
Water absorption capacity & $0.23 \pm 0.01 \mathrm{~b}$ & $0.26 \pm 0.01 \mathrm{a}$ & $0.18 \pm 0.01 \mathrm{c}$ \\
Penetrate rate $\left(\mathrm{g} \cdot \mathrm{min}^{-1}\right)$ & $4.49 \pm 0.04 \mathrm{a}$ & $4.01 \pm 0.12 \mathrm{~b}$ & $3.04 \pm 0.18 \mathrm{c}$ \\
Evaporation rate $\left(\mathrm{g} \cdot \mathrm{h}^{-1}\right)$ & $0.59 \pm 0.01 \mathrm{a}$ & $0.50 \pm 0.01 \mathrm{~b}$ & $0.37 \pm 0.01 \mathrm{c}$ \\
Total nitrogen $\left(\mathrm{mg} \cdot \mathrm{g}^{-1}\right)$ & $7.09 \pm 0.78 \mathrm{a}$ & $3.11 \pm 0.05 \mathrm{~b}$ & $1.20 \pm 0.03 \mathrm{c}$ \\
Total phosphorus $\left(\mathrm{mg}^{-1}\right)$ & $0.71 \pm 0.04 \mathrm{a}$ & $0.34 \pm 0.09 \mathrm{~b}$ & $0.32 \pm 0.01 \mathrm{~b}$ \\
Available phosphorus $\left(\mathrm{mg} \cdot \mathrm{kg}^{-1}\right)$ & $13.10 \pm 0.82 \mathrm{a}$ & $5.04 \pm 0.21 \mathrm{~b}$ & $12.75 \pm 0.69 \mathrm{a}$ \\
\hline
\end{tabular}

Note: the different letters in the same line indicate significant difference among the different treatments $(p<0.05)$; The same below (LSD test); all data were mean \pm standard error (mean \pm SE). 


\subsubsection{Root Tip Morphological and Chemical Traits}

In the laboratory, the root samples for morphological trait analysis were carefully dissected with forceps based on their branching order, following the procedure described in [17] and [20], with the distal nonwoody roots regarded as first-order roots. Then, the root samples of each species were scanned with an Expression 10000XL 1.0 scanner at the Northeast Forestry University (Epson Telford Ltd., Telford, UK). The mean diameter, total length, and volume of the root tips (first-order roots) were determined using Root System Analyzer software (WinRhizo 2004b, Regent Instruments, Inc., Québec, Canada). Next, these root samples were oven-dried $\left(65^{\circ} \mathrm{C}, 48 \mathrm{~h}\right)$, weighed $( \pm 0.0001 \mathrm{~g})$, and their specific root length (SRL), root surface area (SRA), average diameter (AD), and root tissue density (RTD) were calculated.

For the root chemical analyses, as mentioned above, the fine root sample (after scanning) was dried $\left(65^{\circ} \mathrm{C}, 48 \mathrm{~h}\right)$ and weighed $( \pm 0.0001 \mathrm{~g})$. The dried fine root sample was ground and homogenized by using a ball mill instrument (RETSCH MM 400, GmbH, Haan, Germany), and $1 \mathrm{~g}$ of the dry powder sample was weighed and pressed with a FYD-20 electric tableting machine (Nuoleixinda Technology Co., Ltd., Tianjin, China) to form a plate that was $6 \mathrm{~mm}$ thick with a diameter of approximately $13 \mathrm{~mm}$. For the pellet sample, the tableting conditions were adjusted according to the actual situation, and the test parameters were maintained (16 MPa, $3 \mathrm{~min})$. The carbon $(\mathrm{C})$, nitrogen $(\mathrm{N})$, and phosphorus $(\mathrm{P})$ elements in the sample were measured after tableting using a J200 Tandem laser spectroscopic element analyzer (Applied Spectra, Inc., Fremont, CA, USA).

\subsubsection{NSC Concentration}

The NSC concentration was defined as the sum of soluble sugar (SS) and starch (ST) concentrations that were measured using the anthrone method [43]. The root sample $(0.1000 \mathrm{~g})$ was placed into a $10 \mathrm{~mL}$ centrifuge tube with the addition of $2 \mathrm{~mL}$ of $80 \%$ ethanol. The mixture was incubated at $80^{\circ} \mathrm{C}$ in a shaking water bath for $30 \mathrm{~min}$ and centrifuged at $4000 \mathrm{rpm}$ for $5 \mathrm{~min}$. Next, two extractions from the pellets were carried out with $80 \%$ ethanol. The supernatant was retained, combined, and stored at $-20{ }^{\circ} \mathrm{C}$ for soluble sugar determination.

Starch was extracted from the ethanol-insoluble pellet following removal of the ethanol by evaporation. The starch in the residue was then released by boiling in $2 \mathrm{~mL}$ distilled water for $15 \mathrm{~min}$. After cooling at room temperature, $2 \mathrm{~mL} 9.2 \mathrm{M} \mathrm{HClO}_{4}$ was added, and the mixture was shaken for $15 \mathrm{~min}$. Next, $4 \mathrm{~mL}$ distilled water was added, and the mixture was centrifuged at $4000 \mathrm{rpm}$ for $5 \mathrm{~min}$. A further extraction was carried out with $2 \mathrm{~mL} 4.6 \mathrm{M} \mathrm{HClO}_{4}$. The supernatant was also retained, combined, and stored at $-20^{\circ} \mathrm{C}$ for starch determination.

Sugar and starch determination was performed based on the absorbance at $625 \mathrm{~nm}$ using the same anthrone reagent in a spectrophotometer [43]. Sugar concentration was calculated using the regression equations based on the standard glucose solutions and starch concentrations by multiplying the glucose concentration with a conversion factor of 0.9 [44].

\subsection{Data Analysis}

A multiway ANOVA of root tip morphological and chemical traits was performed using SPSS 19.0 (IBM Co., Armonk, NY, USA) to examine the differences in the root tip traits of seedlings between different treatments (LSD, $\alpha=0.05$ ). Principal component analysis (PCA) and redundancy analysis (RDA) were performed on the root tip traits of seedlings under different treatments using the Canoco software for Windows (Version 4.56, Biometris Plant Research International Wageningen, The Netherlands). A Monte Carlo replacement test was performed on the parameters in the RDA analysis using vegan package in $\mathrm{R}$ language [45]. Regression analysis was used to determine the relationship between the specific root length, mean diameter, and NSCs. All data were represented as the mean \pm standard error (mean $\pm \mathrm{SE}$ ). 


\section{Results}

\subsection{Root Tip Morphology}

All root tip morphological traits were significantly different among the three tree species. J. mandshurica (JM) had a comparatively larger SRL and SRA but a lower RTD and a smaller AD than F. mandshurica (FM) and P. amurense (PA) (Figure 1A,C,E,G; $p<0.01$ ). In JM and FM, the SRL and SRA significantly increased with an increase in the intensity of drought treatments $(p<0.05)$. Compared with CK, the SRL and SRA of the three species were significantly increased in T3, with an average range for the soil substrates of $17.22 \%$ and $14.77 \%$, while in JM and FM, the RTD and AD did not change significantly under drought treatment $(p>0.05)$. The SRL of JM, FM, and PA, respectively, increased by $13.23 \%, 26.08 \%$, and $33.46 \%$ in sandy-loam soil compared to the values in humus soil (Figure 1B). The RTD of JM, FM, and PA, respectively, increased by $18.53 \%, 22.89 \%$, and $19.15 \%$ in humus soil compared to the values in sandy-loam soil (Figure 1H). Variations in the SRA and AD of the three tree species according to different substrates were not considered significant (Figure 1D,F). The interactions between species-water, species-soil, and water-soil did not significantly change the root morphological traits.
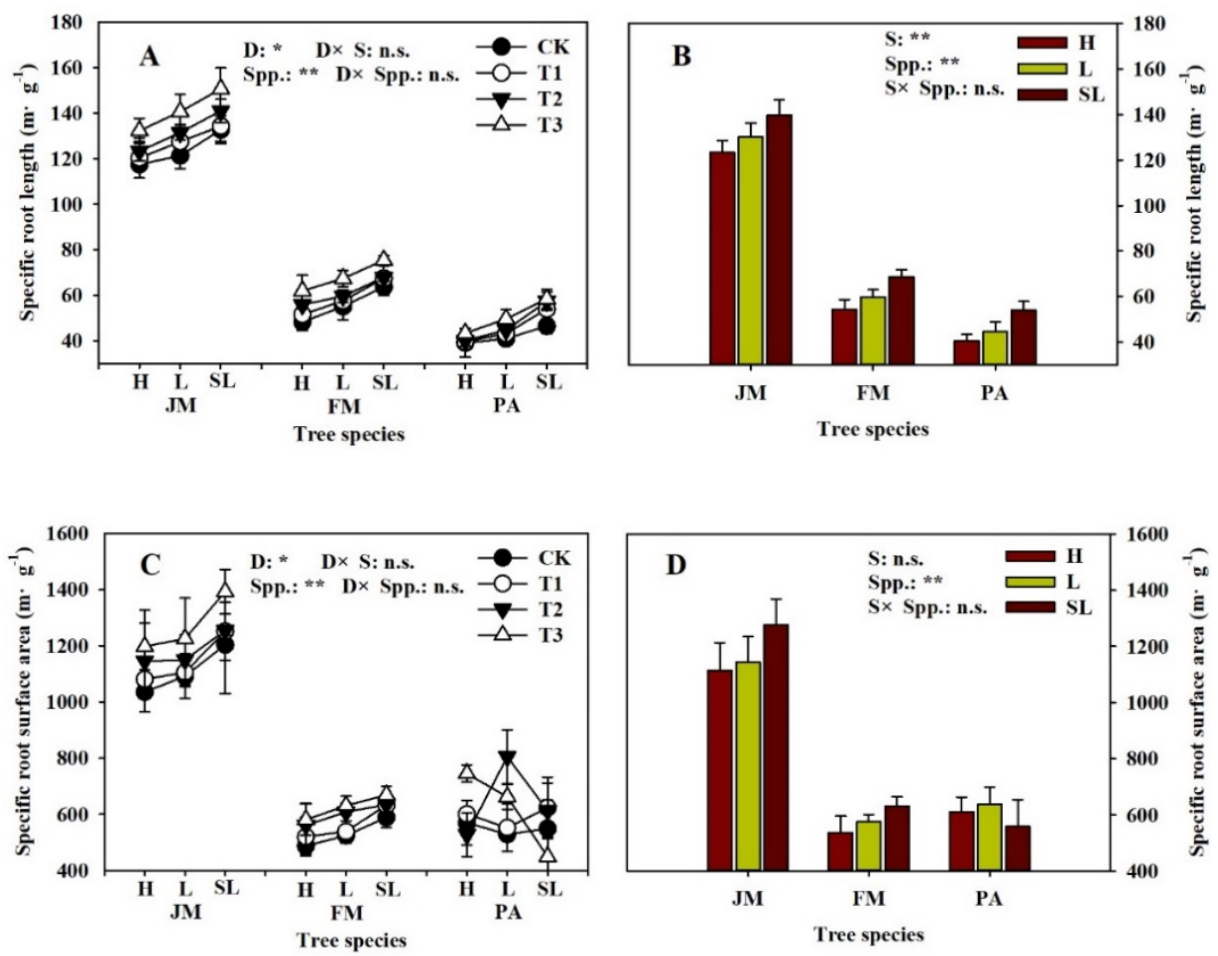

Figure 1. Cont. 

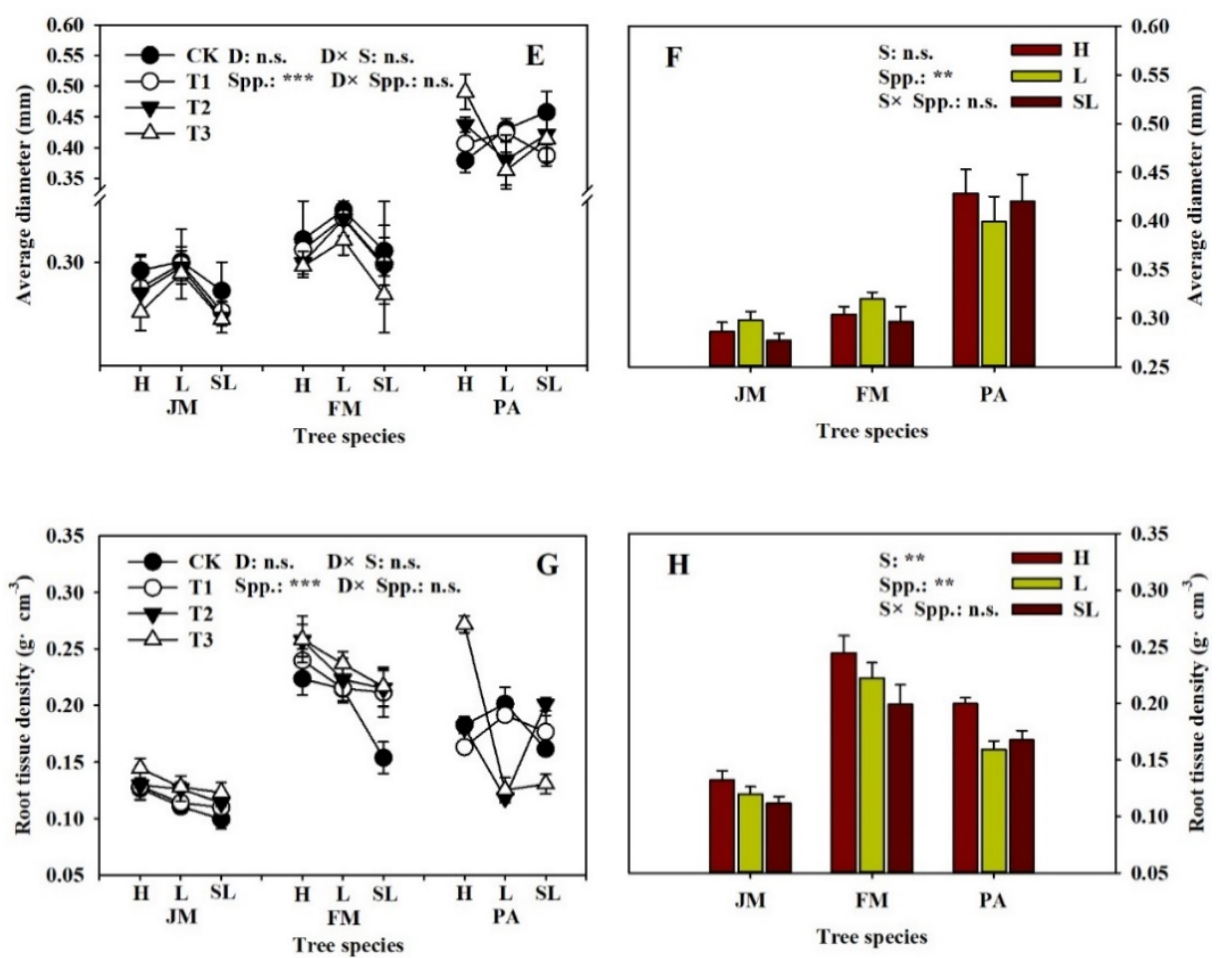

Figure 1. Root tip morphological traits $((\mathbf{A}, \mathbf{B})$ Specific root length; $(\mathbf{C}, \mathbf{D})$ Specific root surface area; (E,F) Average diameter; $(\mathbf{G}, \mathbf{H})$ Root tissue density) in different drought and soil substrates. The histogram represents the average values across four drought treatments. The error bars represent SEM. H, humus; L, loam; SL, sandy-loam; JM, Juglans mandshurica Maxim.; FM, Fraxinus mandshurica Rupr.; PA, Phellodendron amurense Rupr. CK, control; T1, mild drought; T2, moderate drought; T3, severe drought; n.s. denotes not significant; D, drought stress; S, soil substrates; Spp., species; ${ }^{*}, p<0.05$; **, $p<0.01 ;{ }^{* * *}, p<0.001$.

\subsection{Root Tip Carbon, Nitrogen, and Phosphorus}

Variations in the root tip $\mathrm{N}$ concentration were significantly explained by species (Table 2, $p=007$ ). The root $\mathrm{N}$ concentration for JM was higher in humus soil under $\mathrm{T} 2$ and $\mathrm{T} 3$ treatments than that in $\mathrm{CK}$. The root N concentration for FM was 11.89\% higher in sandy-loam soil in T3 than that in CK (Table 3, $p<0.05)$. Compared to CK, PA had a lower N concentration in humus soil in T1 and T2. Drought did not significantly affect the root $\mathrm{C}$ and $\mathrm{N}$ concentrations in the three tree species, while the soil substrate significantly changed the root $C, N$, and $P$ concentrations (Table $2, p_{C}<0.001 ; p_{N}<0.001 ; p_{P}=0.003$ ). However, the root $\mathrm{C}, \mathrm{N}$, and $\mathrm{P}$ concentrations significantly differed considering the soil-species and drought-soil-species interactions (Table $2, p<0.01$ ).

Table 2. Results of three-way (drought intensity $\times$ soil substrates $\times$ species) factorial ANOVA of chemical traits of the root tip. Values in bold type indicate significant effects.

\begin{tabular}{|c|c|c|c|c|c|c|c|}
\hline \multirow{2}{*}{ Source of Variation } & \multirow{2}{*}{$\mathrm{df}$} & \multicolumn{2}{|c|}{$\mathrm{C}$} & \multicolumn{2}{|c|}{$\mathbf{N}$} & \multicolumn{2}{|c|}{$\mathbf{P}$} \\
\hline & & F & $p$ & F & $p$ & F & $p$ \\
\hline $\mathrm{D}$ & 3 & 0.399 & 0.754 & 0.188 & 0.904 & 3.001 & 0.036 \\
\hline S & 2 & 22.109 & $<0.001$ & 11.669 & $<0.001$ & 6.191 & 0.003 \\
\hline Spp. & 2 & 2.461 & 0.092 & 5.369 & 0.007 & 2.03 & 0.139 \\
\hline $\mathrm{D} \times \mathrm{S}$ & 6 & 1.745 & 0.123 & 0.895 & 0.503 & 2.405 & 0.036 \\
\hline $\mathrm{D} \times$ Spp & 6 & 1.897 & 0.093 & 2.226 & 0.050 & 4.567 & 0.001 \\
\hline$S \times S p p$ & 4 & 19.142 & $<0.001$ & 16.257 & $<0.001$ & 13.802 & $<0.001$ \\
\hline $\mathrm{D} \times \mathrm{S} \times \mathrm{Spp}$ & 12 & 3.801 & $<0.001$ & 2.871 & 0.003 & 2.245 & 0.018 \\
\hline
\end{tabular}

D, drought stress; S, soil substrates; Spp., species. 
Table 3. Root tip carbon, nitrogen, and phosphorus in different drought, soil substrates, and species.

\begin{tabular}{|c|c|c|c|c|c|c|c|c|c|c|}
\hline \multirow{2}{*}{$\begin{array}{c}\text { Soil } \\
\text { Substrates }\end{array}$} & \multirow{2}{*}{$\begin{array}{c}\text { Drought } \\
\text { Stress }\end{array}$} & \multicolumn{3}{|c|}{$\mathrm{JM}$} & \multicolumn{3}{|c|}{ FM } & \multicolumn{3}{|c|}{ PA } \\
\hline & & $\mathrm{C}(\%)$ & N (\%) & $p(\%)$ & $\mathrm{C}(\%)$ & N (\%) & $p(\%)$ & $\mathrm{C}(\%)$ & N (\%) & $p(\%)$ \\
\hline \multirow{5}{*}{$\mathrm{H}$} & CK & $41.35 \pm 0.12 a$ & $2.12 \pm 0.01 b$ & $0.23 \pm 0.01 \mathrm{a}$ & $41.05 \pm 0.03 a$ & $2.06 \pm 0.02 a$ & $0.25 \pm 0.01 a$ & $41.17 \pm 0.08 a$ & $2.10 \pm 0.03 a$ & $0.25 \pm 0.01 \mathrm{a}$ \\
\hline & $\mathrm{T} 1$ & $41.30 \pm 0.12 a$ & $2.12 \pm 0.02 \mathrm{a}$ & $0.24 \pm 0.01 \mathrm{a}$ & $41.05 \pm 0.05 a$ & $2.06 \pm 0.03 a$ & $0.25 \pm 0.01 \mathrm{a}$ & $41.04 \pm 0.01 a$ & $2.03 \pm 0.01 b$ & $0.25 \pm 0.01 \mathrm{a}$ \\
\hline & $\mathrm{T} 2$ & $41.41 \pm 0.16 a$ & $2.16 \pm 0.06 a b$ & $0.23 \pm 0.01 \mathrm{a}$ & $41.09 \pm 0.05 a$ & $2.08 \pm 0.03 a$ & $0.25 \pm 0.01 \mathrm{a}$ & $41.16 \pm 0.02 \mathrm{a}$ & $2.07 \pm 0.01 \mathrm{ab}$ & $0.24 \pm 0.01 \mathrm{a}$ \\
\hline & T3 & $41.51 \pm 0.11 \mathrm{a}$ & $2.20 \pm 0.04 a$ & $0.23 \pm 0.01 a$ & $41.01 \pm 0.04 a$ & $2.03 \pm 0.02 \mathrm{a}$ & $0.25 \pm 0.01 \mathrm{a}$ & $41.04 \pm 0.03 a$ & $2.03 \pm 0.01 b$ & $0.25 \pm 0.01 \mathrm{a}$ \\
\hline & CK & $41.12 \pm 0.08 \mathrm{a}$ & $2.06 \pm 0.03 a$ & $0.25 \pm 0.01 a$ & $41.02 \pm 0.06 b$ & $2.04 \pm 0.03 a$ & $0.25 \pm 0.01 \mathrm{a}$ & $41.00 \pm 0.15 a$ & $2.01 \pm 0.06 a$ & $0.25 \pm 0.01 \mathrm{a}$ \\
\hline \multirow{2}{*}{$\mathrm{L}$} & $\mathrm{T} 1$ & $40.98 \pm 0.02 \mathrm{ab}$ & $2.00 \pm 0.01 b c$ & $0.25 \pm 0.01 b c$ & $41.05 \pm 0.08 b$ & $2.07 \pm 0.04 a$ & $0.25 \pm 0.01 \mathrm{a}$ & $41.00 \pm 0.04 a$ & $2.01 \pm 0.02 \mathrm{a}$ & $0.25 \pm 0.01 \mathrm{a}$ \\
\hline & $\mathrm{T} 2$ & $40.87 \pm 0.03 b$ & $1.96 \pm 0.01 c$ & $0.26 \pm 0.01 c$ & $41.01 \pm 0.04 b$ & $2.04 \pm 0.02 a$ & $0.25 \pm 0.01 a$ & $41.11 \pm 0.06 a$ & $2.06 \pm 0.03 a$ & $0.25 \pm 0.01 \mathrm{a}$ \\
\hline \multirow{4}{*}{ SL } & CK & $41.03 \pm 0.01 \mathrm{a}$ & $2.02 \pm 0.01 a$ & $0.25 \pm 0.01 a$ & $41.00 \pm 0.13 a$ & $2.02 \pm 0.06 b$ & $0.25 \pm 0.01 \mathrm{a}$ & $41.08 \pm 0.04 a$ & $2.05 \pm 0.02 \mathrm{a}$ & $0.25 \pm 0.01 \mathrm{a}$ \\
\hline & $\mathrm{T} 1$ & $40.97 \pm 0.02 \mathrm{ab}$ & $2.00 \pm 0.01 b$ & $0.25 \pm 0.01 b$ & $41.24 \pm 0.09 a$ & $2.16 \pm 0.05 a b$ & $0.24 \pm 0.01 \mathrm{a}$ & $41.05 \pm 0.04 a$ & $2.03 \pm 0.02 a$ & $0.25 \pm 0.01 \mathrm{a}$ \\
\hline & $\mathrm{T} 2$ & $40.93 \pm 0.01 b$ & $1.98 \pm 0.01 b c$ & $0.25 \pm 0.01 b c$ & $41.15 \pm 0.07 a$ & $2.11 \pm 0.03 \mathrm{ab}$ & $0.25 \pm 0.01 \mathrm{a}$ & $41.09 \pm 0.07 a$ & $2.05 \pm 0.03 a$ & $0.25 \pm 0.01 \mathrm{a}$ \\
\hline & $\mathrm{T} 3$ & $40.92 \pm 0.03 b$ & $1.98 \pm 0.01 c$ & $0.25 \pm 0.01 c$ & $41.44 \pm 0.10 \mathrm{a}$ & $2.26 \pm 0.05 a$ & $0.24 \pm 0.01 \mathrm{a}$ & $40.93 \pm 0.10 a$ & $1.98 \pm 0.04 a$ & $0.25 \pm 0.01 \mathrm{a}$ \\
\hline
\end{tabular}

Note: the different letters indicate significant difference among the drought treatments in same soil substrates ( $p<0.05)$; The same below. H, humus; L, loam; SL, sandy-loam; JM, Juglans mandshurica Maxim.; FM, Fraxinus mandshurica Rupr.; PA, Phellodendron amurense Rupr. CK, control; T1, light drought; T2, moderate stress; T3, severe stress; all data were mean \pm standard error (mean $\pm \mathrm{SE})$ 


\subsection{Root Tip NSC Concentration}

Root tip soluble sugars (SS), starch, and NSCs significantly decreased under drought treatments in the three tree species (Figure 2). With an increase of drought intensity, the root SS, ST, and total NSC concentrations were significantly affected. The root SS, ST, and total NSC concentrations for JM in T3 significantly decreased, respectively, by $40.20 \%, 79.12 \%$, and $72.80 \%$ on average for the soil substrates compared to CK (Figure 2A-C). Compared to CK, FM and PA had lower SS, ST, and NSC concentrations in T3 for the three soil substrates. In general, with the exception of ST in FM, the SS and ST concentrations in humus soil were higher than those in the loam and sandy-loam soil. The root SS and ST concentrations for JM in humus soil were, respectively, $29.69 \%$ and $120.53 \%$ higher than those in the sandy-loam soil. The SS concentrations for FM and PA in the humus soil were, respectively, $181.63 \%$ and $97.26 \%$ higher than those in the sandy-loam soil (Figure $2 \mathrm{~B}, \mathrm{D}, p<0.01$ ). Soil substrate, drought, and species had no significant effect on SS/ST (Figure 2G,H). The water-soil and soil-species interactions significantly affected the root ST and NSC concentrations, while no significant change was observed in the SS and ST concentrations under each treatment (Figure 2C-F).
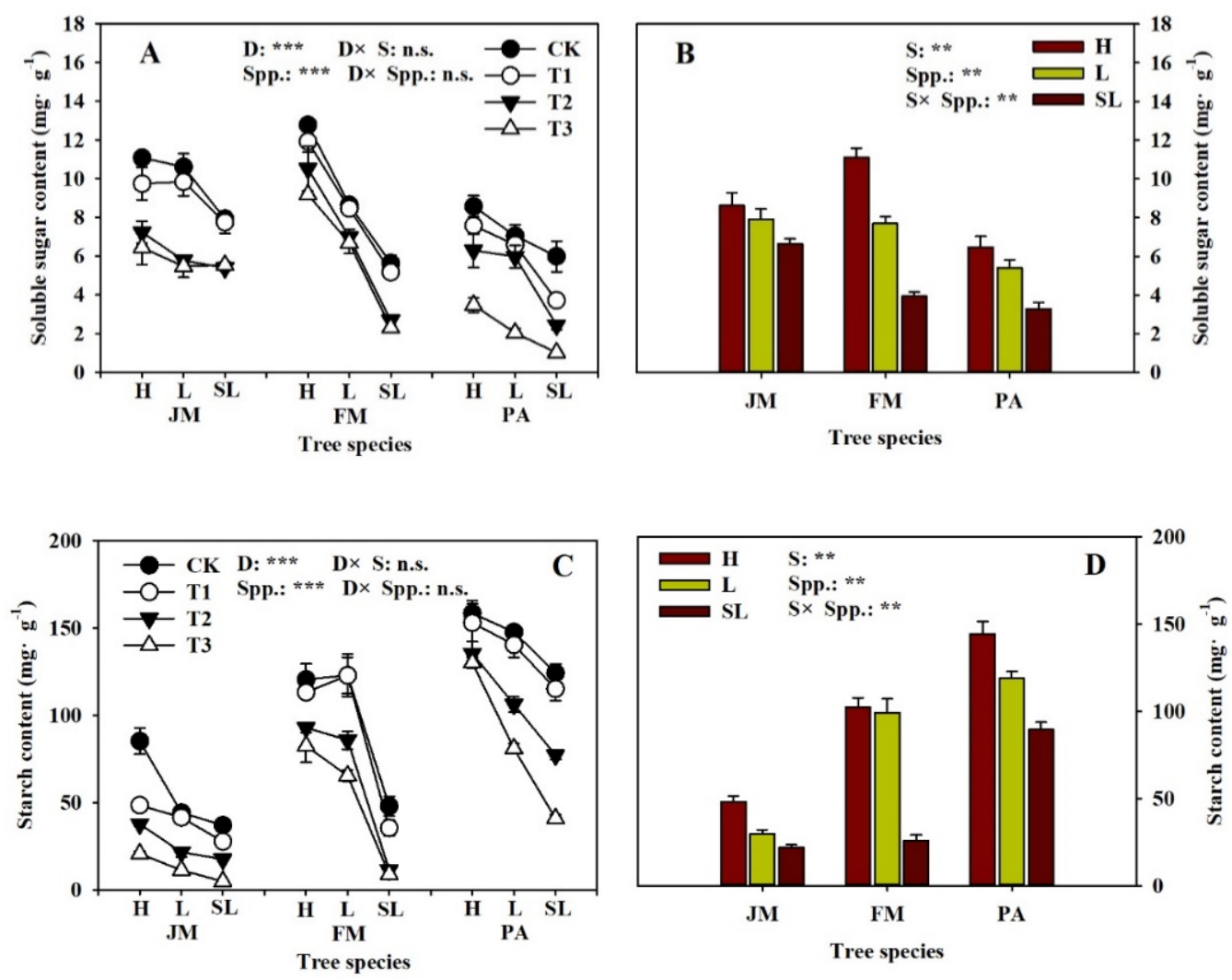

Figure 2. Cont. 

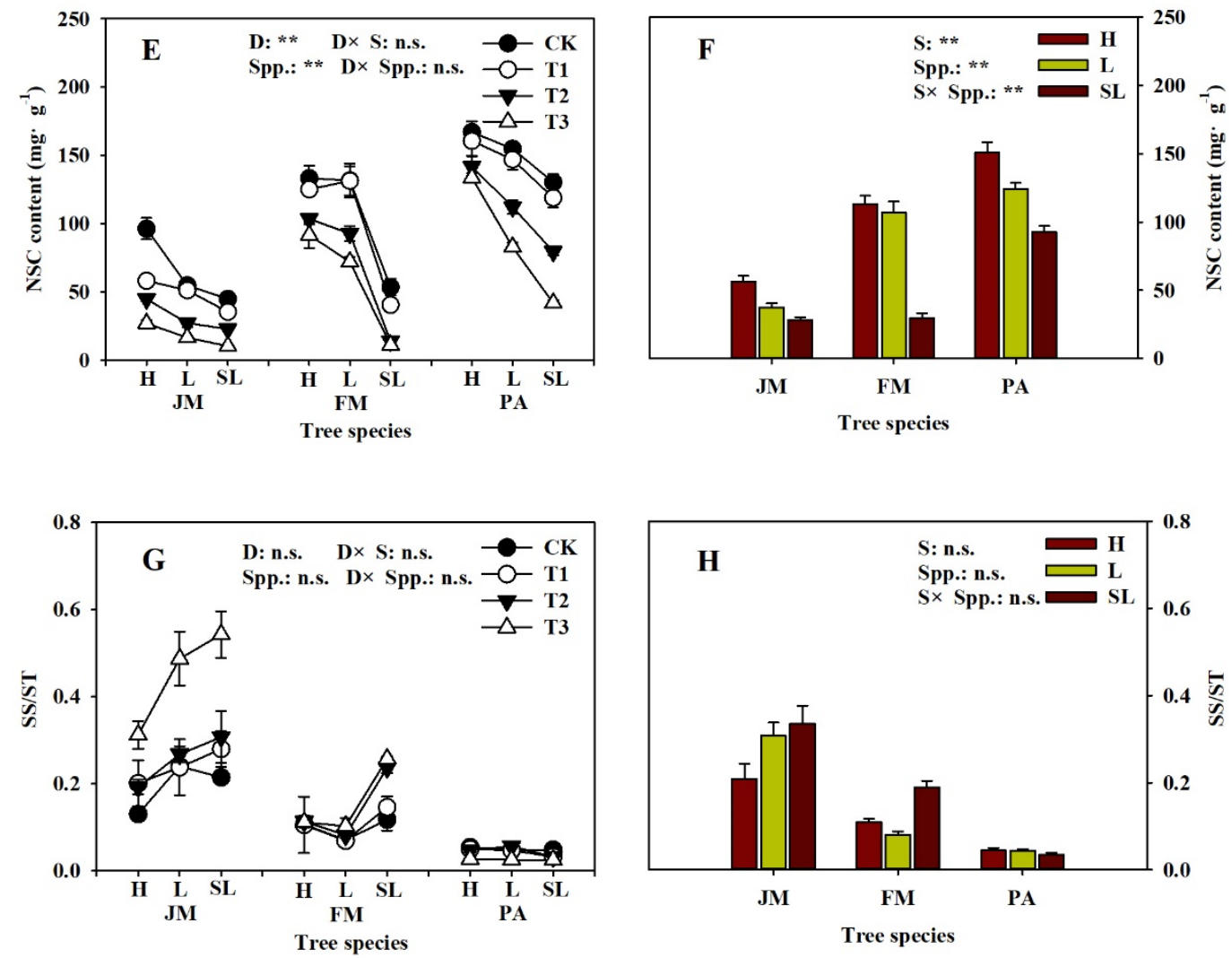

Figure 2. Root tip nonstructural carbohydrate ((A,B) Soluble sugar; (C,D) Starch; (E,F) NSC; (G,H) SS/ST) in different drought and soil substrates. The histogram represents the average values across four drought treatments. The error bars represent SEM. H, humus; L, loam; SL, sandy-loam; JM, Juglans mandshurica; FM, Fraxinus mandshurica; PA, Phellodendron amurense. CK, control; T1, mild drought; T2, moderate drought; T3, severe drought; n.s. denotes not significant; D, drought stress; S, soil substrates; Spp., species; ${ }^{*}, p<0.05 ;{ }^{* *}, p<0.01 ;{ }^{* * *}, p<0.001$.

\subsection{Relationship between Root Tip Morphology and NSC}

By analyzing the root morphological and chemical traits under different water and soil conditions in the three temperate tree species, the first two axes of the redundancy analysis (RDA) explained approximately $90 \%$ of the total variations between all treatments (Figure 3). The degrees of separation of different tree species were better than those of water and soil. However, the root morphological and chemical traits under all treatments were subjected to a Monte Carlo test, while the root ST and NSC concentrations were the main influential factor of the first and second sorting axis, respectively (ST: $R^{2}=0.451, p<0.001$; NSC: $R^{2}=0.637, p<0.001$ ). Therefore, the root SS and ST concentrations were positively and negatively correlated with SRL and negatively and positively correlated with AD. 


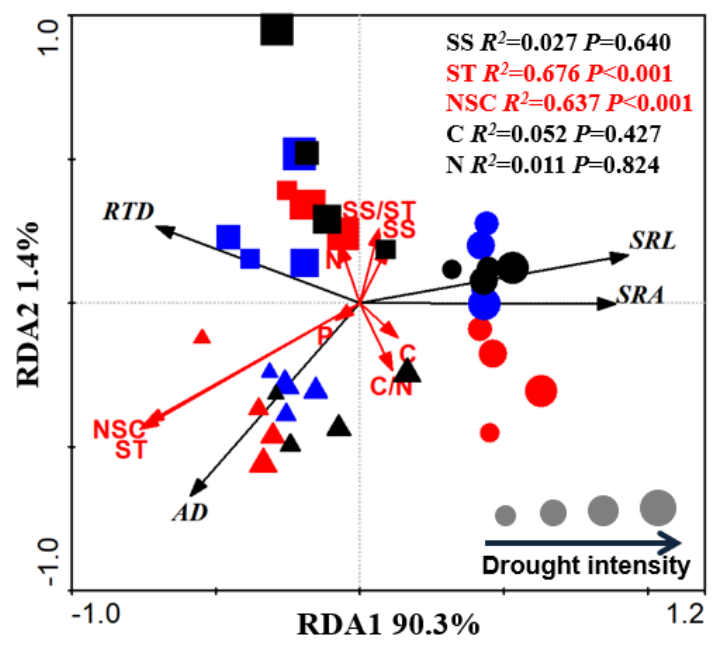

Figure 3. Redundancy analysis of root tip morphological and chemical traits in different drought, soil substrates and species. Red, humus; blue, loam; black, sandy-loam; circle, JM; square; FM; triangle, PA; SRL, specific root length; SRA, specific root surface area; AD, average diameter; RTD, root tissue density; SS, soluble sugar; ST, starch; C, carbon; N, nitrogen; P, phosphorus.

The root SS concentration was significantly affected by the treatments in all three species, but the treatments had no significant effect on the SRA and RTD, while the average diameter explained up to $6.8 \%$ of the total variation in soluble sugar (Figure $4 \mathrm{~A}, \mathrm{~B} ; p<0.001$ ). A significant correlation was observed between root ST concentrations and SRA, RTD, SRL, and AD; the SRL and AD, respectively, explain up to $32.1 \%$ and $28.4 \%$ ( $48.4 \%$ and $38.9 \%$ without ' $I n$ ' conversion, respectively) of the total variations in starch concentrations (Figure $4 \mathrm{~A}, \mathrm{~B} ; p<0.001$ ). There was no significant correlation between root $\mathrm{C}, \mathrm{N}, \mathrm{P}$, and NSC concentrations under different treatments (data not shown).
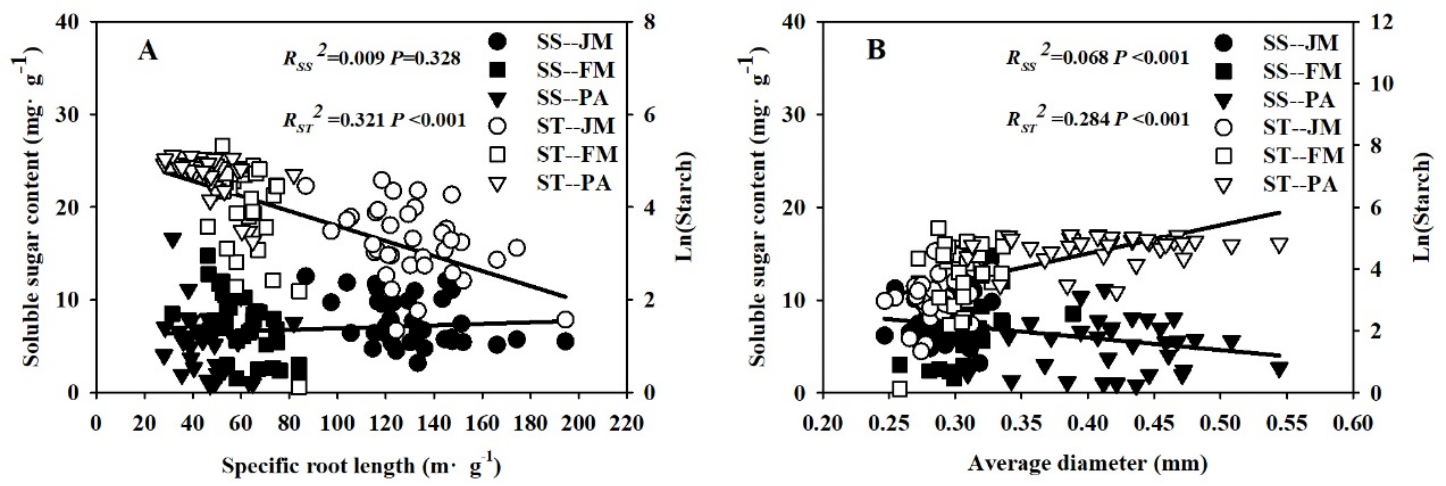

Figure 4. Relationships of the SS and ST concentrations with SRL (A) and AD (B) of root tip in the three specie. SS, soluble sugar (black symbol); ST, starch (white symbol). Data for starch concentration data had undergone ln conversion.

\section{Discussion}

\subsection{Response of Root Morphological Traits to Drought and Soil Substrates}

According to our first hypothesis, the root morphological traits of all three species, especially the SRL, significantly changed under drought stress and different soil substrates. With increased drought intensity, the roots showed a larger SRL, SRA, a finer AD, and a higher RTD. Through their meta-analysis, Ostonen et al. [46] documented that SRL can be used as an indicator for plant drought stress tolerance. Olmo et al. [47] studied 10 different tree and shrub species and revealed that very fine root (root diameter $<0.5 \mathrm{~mm}$ ) biomass significantly decreased under drought conditions, while very 
fine root biomass and SRL increased, but AD and tissue $\mathrm{N}$ concentrations decreased. According to the traditional resource economic hypothesis, plants grown on poor soils should maintain their fine roots by adjusting their morphological plasticity, thereby maintaining a lower SRL (thicker and longer lifespan) to retain scarce resources (conservative strategy). Similarly, the plants grown on soil with sufficient nutrient availability are more likely to have a higher SRL to obtain soil resources efficiently and quickly (acquisition strategy) [48-50]. Conversely, some researchers have suggested that poor soils can cause plant fine roots to have a higher SRL (i.e., thinner with a shorter lifespan) because these roots can obtain nutrients faster and more effectively [51-53]. This trade-off between resource conservation and acquisition shows that fine root traits may also play a critical role within species. Our results are consistent with the latter hypothesis. However, in sandy-loam soil with relatively poor soil conditions, the root tip has a larger SRL, SRA, and a lower RTD. The SRL of JM, FM, and PA were increased by $13.23 \%, 26.08 \%$, and $33.46 \%$ in sandy-loam soil compared to the values in humus soil, respectively. These results indicate that the variations in fine root morphology are mainly affected by the availability of soil resources. Weemstra et al. [26] revealed that the fine root SRL and RTD of beech and spruce do not significantly differ for clay vs. sandy soils. These fluctuations in fine roots suggest that their research sites were in field plots rather than in greenhouse pots, as the biotic and abiotic factors under field conditions are relatively complex.

The minute changes in fine root AD, SRL, and SRA could result in dramatic changes [54], and increases in root length mean that the absorption range of the root system in the soil has expanded [55]. Soil nitrogen deficiency usually promotes the growth of the primary root, particularly lateral root elongation but not lateral root initiation [56], while the formation of lateral roots is almost completely absent under severe $\mathrm{N}$ shortage [57]. In a nutrient-rich environment, the RTD was significantly higher than that in nutrient-poor environments. Previous studies have shown that RTD is positively corelated with root dry matter [58] and also with the root respiration rate [59] as plants can invest more photosynthetic products in maintaining root lifespan, resulting in a lower relative growth rate of the aboveground plants [60]. Therefore, there is a trade-off relationship between root carbohydrate input and aboveground productivity [61]. Plants usually increase their ability to capture nutrients through root plasticity under nutrient-deficient soil [62], the specific performance of which expands the absorption range or improves the absorption capacity in situ. Accordingly, a higher root density, branching density, root length, SRL, $\mathrm{AD}$, and root volume were observed in nutrient-deficient soil compared to those under higher nutrient soil [54]. Thus, our results indicate that the seedlings significantly increased main root growth, lateral root elongation, and branching intensity of their fine roots, thereby expanding the distribution of roots in the soil and improving their ability to absorb soil resources. The seedlings with higher SRL, SRA, and number of root tips had significantly increased ability to absorb and utilize soil resources in situ [27] due to the establishment of a dense root network system [63]. This system also consumes more photosynthetic products due to accelerated fine root turnover. A higher root diameter and volume (PA) means that there were more coarse roots, which can be helpful in improving plant resistance to stress and the rapid growth of aerial parts.

\subsection{Effect of Drought and Soil Substrates on Fine Root NSC Concentration}

Nonstructural carbohydrates (NSCs) are an important component of plant carbon budgets. The content of soluble sugar in plants varies greatly over the entire plant growth and development, and is closely related to changes in environmental factors. Further, NSC adjustment is an important mechanism for adapting to environmental fluctuations [64]. Some previous studies have demonstrated that the degree of drought stress in trees is reflected by NSC concentrations. Therefore, NSCs could be used by plants to maintain root respiration, metabolism, and production, while severe drought stress can lead to a decline in NSC concentrations [65,66]. Zang et al. [67] documented that drought reduced the photosynthetic and root respiration rates in Fagus sylvatica L. leaves, but water deficit did not show such a relationship between drought, fine root starch, and NSC concentrations, except for fructose. A further study by Galvez et al. [68] revealed that Populus tremuloides Michx. can adapt to drought 
by transforming its growth into root reserves with a two times higher starch concentration. Under severe drought intensity, Norway spruce, two eucalyptus species, and radiata pine showed lower concentrations of starch and sugar $[9,69]$. In our current study, the concentrations of soluble sugar and starch in roots in all three species gradually decreased with increasing drought intensity, and lower concentrations were observed in sandy-loam soil. However, in accordance with our second hypothesis, JM and FM (with a thinner root diameter) had higher SS concentrations compared to PA, while the starch concentrations were higher in trees with thinner root diameters (JM and FM) and lower in those with larger root diameters (PA). Thicker roots have relatively larger total cross-sectional areas of stele, and generally have a longer lifespan and lower turnover rate; thus, these roots can resist environmental stress, mechanical damage, and the feeding of soil animals [70]. Similarly, thicker roots have a relatively smaller cortical area, lower $\mathrm{N}$ content, and a slower metabolic rate [19,71,72]. Fort et al. [73] documented that thinner fine roots have a fast resource acquisition strategy to absorb larger amounts of water in a shorter time period and can consume larger amounts of water under water deficit conditions. Conversely, species with more conservative strategies have thicker roots and absorb less water during peak growth seasons while retaining their water uptake over long periods of time and consuming less water during periods of low water availability. We conclude that the JM roots with smaller diameters under drought stress have a larger SRL and can maintain their own growth (per unit of root length) by investing less carbohydrates and maintaining more nutrients; in return, they consume less SS to withstand stress conditions. Fort et al. [73] and Padilla et al. [74] found that drought-to-fast-resources have less of an impact on species than conservation strategies through short-term drought simulation experiments; the latter survive more efficiently in long-term droughts [49]. Plants with thicker roots generally have longer lifespans and greater transportive capabilities [75,76]. In our study, compared with JM and FM, PA (thicker root) contained higher starch and NSC concentrations, which could ensure long-term survival under adverse environmental conditions.

\subsection{Relationship between Root SRL, Diameter, and NSC Concentration}

Root diameter and SRL are the most common parameters of fine root $(<2 \mathrm{~mm})$ morphology and have been extensively studied as indicators under diverse environmental conditions, such as soil nutrient availability and drought stress [52]. The three compound leaf species in this study were clearly separated by two morphological axes, reflecting the different response mechanisms of different diameter gradients facing environmental fluctuations (Figure 3). The RDA1 axis was closely related to the SRL and SRA and was recognized as an acquisition strategy axis (Figure 3). The JM distributed on the right side of the axis among the three compound leaf species indicating its high capability to acquire soil resources (per root mass with a higher root length). Species of this strategy generally have shorter lifespans and more branches under diverse conditions, and mostly occur in moist soils [77]. Conversely, the species that are typically distributed around the RDA2 axis may be more inclined to employ a conservative strategy, indicating that the species can invest more biomass into their roots and maintain a longer lifespan under drought; these trees are distributed in cooler and drier areas [77]. Starch and NSC concentrations were negatively correlated to the ability to acquire resources (the higher the starch and NSC, the lower the SRL and SRA, such as in PA). The root lifespan of such species was relatively longer under a conservative strategy, maintaining a higher starch concentration and a low level of soluble sugar in order to avoid animal feeding, mechanical damage, etc. [78]. Guo et al. [79] documented that NSC concentrations are maintained by the construction and maintenance of fine roots with a diameter of $0.35 \mathrm{~mm}$ and are much lower than those in fine roots with a diameter of $0.80 \mathrm{~mm}$. A correlation analysis between the root morphology and NSC concentrations of the three compound leaf species showed that SRL and starch are negatively correlated with each other, which could explain up to $32.1 \%$ of the total variation. However, the AD was negatively correlated with soluble sugar and positively correlated with starch and can explain $6.8 \%$ and $28.4 \%$ of the total variation, respectively. Some previous studies have demonstrated that under constant root tissue density, the SRL is closely correlated to the reciprocal of the AD square in temperate forest [24,75,80-82], subtropical forest [83-85], 
and boreal forest [52]. Meanwhile, the SRL demonstrates high correlation with root respiration [86]. NSC is an important substrate for root respiration and can stimulate the root respiration rate $[87,88]$. Previous studies reporting on the relationship between fine root diameter and respiration found that shallow roots with a thinner diameter have a higher respiratory rate [89-91]. This further suggests that fine roots are very physiologically active $[17,92]$, and their relatively larger SRL provides greater surface area (based on the mass per unit root) for more efficient water and nutrient absorption in heterogeneous soil, which results in a larger respiratory rate. Accordingly, for JM root with relatively larger SRL, shorter root lifespan and higher turnover rates are used to reduce its own losses and, thus, maintain a lower NSC level (acquisition strategy). By contrast, for PA with relatively thicker roots, a longer lifespan and lower turnover rate contribute to maintaining a higher NSC level (a conservative strategy) in order to maintain growth.

\section{Conclusions}

Our study showed that the root morphological traits and NSC concentrations in three temperate tree species are significantly different under drought stress and different soil substrates, but the differences between species were found to be larger than those observed under different drought and soil substrate conditions. The root NSC concentration (soluble sugar and starch) was closely related to the root morphological traits (SRL and AD) but did not correlate with the root $\mathrm{C}$ and $\mathrm{N}$ concentrations. Under a state of different soil resources, the root tip with the thinner diameter had higher SS concentrations, while the root tip with the thicker diameter had higher ST concentrations. Therefore, it was concluded that the three temperate tree species could construct a root system in the most "economical" way under different soil substrates; these species also presented the most beneficial (nutrient acquisition) and cost-effective (root structure and maintenance) relationship. This rationally demonstrates a trade-off in the root resource allocation model and determines the ecological countermeasures for plant adaptation to diverse environmental conditions. However, our research mainly focused on the root traits and NSC concentrations in temperate deciduous tree species. Few previous studies have focused on root anatomical traits under different drought intensities and soil substrates based on the economic spectrum of roots. Therefore, it is necessary to further explore the relationship between the morphological and anatomical root traits of temperate tree species in different climatic zones and taxonomic levels, especially regarding the mechanism underlying NSC levels and fine root lifespan and turnover.

Supplementary Materials: The following are available online at http://www.mdpi.com/1999-4907/11/4/415/s1, Figure S1: A schematic map of the field experimental treatments.

Author Contributions: Experimental design, L.J., D.Y. and Y.Y.; Writing-Original Draft Preparation, L.J.; Writing-Review and Editing, K.A., L.Y. and Y.Y.; Funding Acquisition, L.J. and Y.Y.; Data Curation: L.J. and Y.Y. Investigation: L.J., Z.L. and J.W.; Visualization: L.J. and Y.Y. All authors have read and agreed to the published version of the manuscript.

Funding: This work was financially supported by the National Key Research \& Development Program of China (2017YFD0600605), Jilin Province Science and Technology Development Plan Project (20160203010NY), Jilin Forestry Department Forestry Science and Technology Project (2014-006), Jilin Province Talent Development Fund and the Fundamental Research Funds for the Central Universities (2572019AA07).

Acknowledgments: We thank Wanying, Cui, Sijia Liu, Linlin Cao, and Jianhua Bi for their assistance in the field, and anonymous reviewers for their constructive comments that improved the manuscript.

Conflicts of Interest: The authors declare no conflict of interest.

\section{References}

1. McDowell, N.; Pockman, W.; Allen, C. Mechanisms of plant survival and mortality during drought: Why do some plants survive while others succumb to drought? New Phytol. 2008, 178, 719-739. [CrossRef] 
2. Allen, C.D.; Macalady, A.K.; Chenchouni, H.; Bachelet, D.; Mcdowell, N.; Vennetier, M.; Kitzberger, T.; Rigling, A.; Breshears, D.D.; Hogg, E.H. A global overview of drought and heat-induced tree mortality reveals emerging climate change risks for forests. For. Ecol. Manag. 2010, 259, 660-684. [CrossRef]

3. Anderegg, W.R.L.; Berry, J.A.; Smith, D.D.; Sperry, J.S.; Anderegg, L.D.L.; Field, C.B. The roles of hydraulic and carbon stress in a widespread climate-induced forest die-off. Proc. Natl. Acad. Sci. USA 2012, 109, $233-237$. [CrossRef]

4. IPCC. Climate change 2007: Synthesis report. In Core Writing Team; Pachauri, R.K., Reisinger, A., Eds.; IPCC: Geneva, Switzerland, 2007; p. 104.

5. Smith, A.M.; Stitt, M. Coordination of carbon supply and plant growth. Plant Cell Environ. 2007, 30, 1126-1149. [CrossRef]

6. Wiley, E.; Huepenbecker, S.; Casper, B.B.; Helliker, B.R. The effects of defoliation on carbon allocation: Can carbon limitation reduce growth in favour of storage? Tree Physiol. 2013, 33, 1216-1228. [CrossRef]

7. Myers, J.A.; Kitajima, K. Carbohydrate storage enhances seedling shade and stress tolerance in a neotropical forest. J. Ecol. 2007, 95, 383-395. [CrossRef]

8. Hartmann, H.; Ziegler, W.; Trumbore, S. Lethal drought leads to reduction in nonstructural carbohydrates in norway spruce tree roots but not in the canopy. Funct. Ecol. 2013, 27, 413-427. [CrossRef]

9. Mitchell, P.J.; O'Grady, A.P.; Tissue, D.T.; White, D.A.; Ottenschlaeger, M.L.; Pinkard, E.A. Drought response strategies define the relative contributions of hydraulic dysfunction and carbohydrate depletion during tree mortality. New Phytol. 2013, 197, 862-872. [CrossRef]

10. Piper, F.I.; Fajardo, A. Carbon dynamics of Acer pseudoplatanus seedlings under drought and complete darkness. Tree Physiol. 2016, 36, 1400-1408.

11. Christian, K.R.; Roman, A.; Olivier, B.; Stephan, H.T.; Keel, S.G.; Susanna, P.R.; Steeve, P.; Siegwolf, R.T.W.; Gerhard, Z. Carbon flux and growth in mature deciduous forest trees exposed to elevated $\mathrm{CO}_{2}$. Science 2005, 309, 1360-1362.

12. Wiley, E.; Hoch, G.; Landhausser, S.M. Dying piece by piece: Carbohydrate dynamics in aspen (populus tremuloides) seedlings under severe carbon stress. J. Exp. Bot. 2017, 68, 5221-5232. [CrossRef] [PubMed]

13. Dietze, M.C.; Sala, A.; Carbone, M.S.; Czimczik, C.I.; Mantooth, J.A.; Richardson, A.D.; Vargas, R. Nonstructural carbon in woody plants. Annu. Rev. Plant. Biol. 2014, 65, 667-687. [CrossRef]

14. Mei, L.; Xiong, Y.; Gu, J.; Wang, Z.; Guo, D. Whole-tree dynamics of non-structural carbohydrate and nitrogen pools across different seasons and in response to girdling in two temperate trees. Oecologia 2015, 177, 333-344. [CrossRef]

15. Hartmann, H.; Trumbore, S. Understanding the roles of nonstructural carbohydrates in forest trees from what we can measure to what we want to know. New Phytol. 2016, 211, 386-403. [CrossRef]

16. Mei, L.; Wang, Z.Q.; Cheng, Y.H.; Guo, D.L. A review:factors influencing fine root longevity in forest ecosystems. Acta Phytoecol. Sin. 2004, 28, 704-710. (In Chinese)

17. Pregitzer, K.S.; DeForest, J.L.; Burton, A.J. Fine root architecture of nine North American trees. Ecol. Monogr. 2002, 72, 293-309. [CrossRef]

18. Guo, D.; Xia, M.; Wei, X.; Chang, W.; Liu, Y.; Wang, Z. Anatomical traits associated with absorption and mycorrhizal colonization are linked to root branch order in twenty-three chinese temperate tree species. New Phytol. 2008, 180, 673-683. [CrossRef]

19. Guo, D.; Li, H.; Mitchell, R.J.; Han, W.; Hendricks, J.J.; Fahey, T.J.; Hendrick, R.L. Fine root heterogeneity by branch order: Exploring the discrepancy in root turnover estimates between minirhizotron and carbon isotopic methods. New Phytol. 2010, 177, 443-456. [CrossRef]

20. Wang, Z.; Guo, D.; Wang, X.; Gu, J.; Mei, L. Fine root architecture, morphology, and biomass of different branch orders of two chinese temperate tree species. Plant Soil 2006, 288, 155-171. [CrossRef]

21. Guo, D.; Mitchell, R.J.; Withington, J.M.; Fan, P.P.; Hendricks, J.J. Endogenous and exogenous controls of root life span, mortality and nitrogen flux in a longleaf pine forest: Root branch order predominates. J. Ecol. 2008, 96, 737-745. [CrossRef]

22. Gu, J.; Xu, Y.; Dong, X.; Wang, H.; Wang, Z. Root diameter variations explained by anatomy and phylogeny of 50 tropical and temperate tree species. Tree Physiol. 2014, 34, 415-425. [CrossRef] [PubMed]

23. Chang, W.J.; Guo, D.L. Variation in root diameter among 45 common tree species in temperate, subtropical and tropical forests in china. J. Plant Ecol. 2008, 32, 1248-1257. 
24. Withington, J.M.; Reich, P.B.; Oleksyn, J.; Eissenstat, D.M. Comparisons of structure and life span in roots and leaves among temperate trees. Ecol. Monogr. 2006, 76, 381-397. [CrossRef]

25. Valladares, F.; Sanchez-Gomez, D.; Zavala, M.A. Quantitative estimation of phenotypic plasticity: Bridging the gap between the evolutionary concept and its ecological applications. J. Ecol. 2006, 94, 1103-1116. [CrossRef]

26. Weemstra, M.; Sterck, F.J.; Visser, E.J.W.; Kuyper, T.W.; Goudzwaard, L.; Mommer, L. Fine-root trait plasticity of beech (Fagus sylvatica) and spruce (Picea abies) forests on two contrasting soils. Plant Soil 2016, 415, 175-188. [CrossRef]

27. Poorter, H.; Niklas, K.J.; Reich, P.B.; Oleksyn, J.; Poot, P.; Mommer, L. Biomass allocation to leaves, stems and roots: Meta-analyses of interspecific variation and environmental control. New Phytol. 2012, 193, 30-50. [CrossRef]

28. Sterck, F.J.; Weemstra, M. Plasticity influencing the light compensation point offsets the specialization for light niches across shrub species in a tropical forest understorey. J. Ecol. 2013, 101, 971-980. [CrossRef]

29. Bardgett, R.D.; Van Der Putten, W.H. Belowground biodiversity and ecosystem functioning. Nature 2014, 515, 505-511. [CrossRef]

30. Yu, D.P.; Zhou, W.M.; Bao, Y.; Lin, Q.I.; Zhou, L.; Dai, L.M. Forest management of korean pine and broadleaf mixed forest in northeast china since the implementation of natural forest protection project. Acta Ecol. Sin. 2015, 35, 10-17.

31. Dai, L.; Gao, C.; Deng, H.; Lanzhu, J.I.; Hao, Z.; Wang, Q. Structure characteristics and health distance assessment of various disturbed communities of korean pine and broadleaved mixed forest in Changbai mountains. Chin. J. Appl. Ecol. 2004, 15, 1750. (In Chinese)

32. Zhu, J.J. A review on fundamental studies of secondary forest management. Chin. J. Appl. Ecol. 2002, 13, 1689-1694. (In Chinese)

33. Bharathan, G.; Goliber, T.E.; Moore, C.; Kessler, S.; Pham, T.; Sinha, N.R. Homologies in leaf form inferred from knoxi gene expression during development. Science 2002, 296, 1858-1860. [CrossRef]

34. Klingenberg, C.P.; Duttke, S.; Whelan, S.; Kim, M. Developmental plasticity, morphological variation and evolvability: A multilevel analysis of morphometric integration in the shape of compound leaves. J. Evol. Biol. 2015, 25, 115-129. [CrossRef]

35. Turner, I.M. The Ecology of Trees in the Tropical Rain Forest; Cambridge University Press: Cambridge, UK, 2001.

36. Mokany, K.; Mcmurtrie, R.E.; Atwell, B.J.; Keith, H. Interaction between sapwood and foliage area in alpine ash (Eucalyptus delegatensis) trees of different heights. Tree Physiol. 2003, 23, 949. [CrossRef]

37. Tulik, M.; Marciszewska, K.; Adamczyk, J. Diminished vessel diameter as a possible factor in the decline of european ash (Fraxinus excelsior L.). Ann. For. Sci. 2009, 67, 103. [CrossRef]

38. Niinemets, Ü. Are compound-leaved woody species inherently shade-intolerant? An analysis of species ecological requirements and foliar support costs. Plant Ecol. 1998, 134, 1-11. [CrossRef]

39. Liu, Y.Y.; Song, J.; Wang, M.; Li, N.; Niu, C.Y.; Hao, G.Y. Coordination of xylem hydraulics and stomatal regulation in keeping the integrity of xylem water transport in shoots of two compound-leaved tree species. Tree Physiol. 2015, 35, 1333. [CrossRef]

40. Merine, A.K.; Rodríguez-García, E.; Alía, R.; Pando, V.; Bravo, F. Effects of water stress and substrate fertility on the early growth of acacia senegal and acacia seyal from ethiopian savanna woodlands. Trees 2015, 29, 593-604. [CrossRef]

41. Yang, N.; Ji, L.; Yang, Y.; Yang, L. The influence of tree species on soil properties and microbial communities following afforestation of abandoned land in northeast china. Eur. J. Soil. Biol. 2018, 85, 73-78. [CrossRef]

42. Wei, X.; Li, G.Y.; Lv, L. Water and nutrient preservation of agri-forest residues used as nursery matrix. Sci. Silvae Sin. 2015, 51, 26-34. (In Chinese)

43. Yemm, E.W.; Willis, A.J. The estimation of carbohydrates in plant extracts by anthrone. Biochem. J. 1954, 57, 508-514. [CrossRef]

44. Osaki, M.; Shinano, T.; Tadano, T. Redistribution of carbon and nitrogen compounds from the shoot to the harvesting organs during maturation in field crops. Soil. Sci. Plant Nutr. 1991, 37, 117-128. [CrossRef]

45. R Core Team. R: A Language and Environment for Statistical Computing; R Foundation for Statistical Computing: Vienna, Austria, 2017. 
46. Ostonen, I.; Püttsepp, Ü.; Biel, C.; Alberton, O.; Bakker, M.R.; Lõhmus, K.; Majdi, H.; Metcalfe, D.; Olsthoorn, A.F.M.; Pronk, A.; et al. Specific root length as an indicator of environmental change. Plant Biosyst. 2007, 141, 426-442. [CrossRef]

47. Olmo, M.; Lopez-Iglesias, B.; Villar, R. Drought changes the structure and elemental composition of very fine roots in seedlings of ten woody tree species. Implications for a drier climate. Plant Soil 2014, 384, 113-129. [CrossRef]

48. Eissenstat, D.; Yanai, R. The ecology of root lifespan. Adv. Ecol. Res. 1997, 27, 1-60.

49. Aerts, R.; Chapin, F. The mineral nutrition of wild plants revisited: A re-evaluation of processes and patterns. Adv. Ecol. Res. 1999, 30, 1-67.

50. Reich, P.B. The world-wide 'fast-slow': Plant economics spectrum: A traits manifesto. J. Ecol. 2014, 102, 275-301. [CrossRef]

51. Eissenstat, D. Costs and benefits of constructing roots of small diameter. J. Plant Nutr. 1992, 15, 763-782. [CrossRef]

52. Ostonen, I.; Lõhmus, K.; Helmisaari, H.; Truu, J.; Meel, S. Fine root morphological adaptations in scots pine, norway spruce and silver birch along a latitudinal gradient in boreal forests. Tree Physiol. 2007, 27, 1627-1634. [CrossRef]

53. Prieto, I.; Roumet, C.; Cardinael, R.; Dupraz, C.; Jourdan, C.; Kim, J.H.; Maeght, J.L.; Mao, Z.; Pierret, A.; Portillo, N.; et al. Root functional parameters along a land-use gradient: Evidence of a community-level economics spectrum. J. Ecol. 2015, 103, 361-373. [CrossRef]

54. Comas, L.; Becker, S.; Cruz, V.M.V.; Byrne, P.F.; Dierig, D.A. Root traits contributing to plant productivity under drought. Front. Plant Sci. 2013, 4, 442. [CrossRef] [PubMed]

55. Henke, M.; Sarlikioti, V.; Kurth, W.; Buck-Sorlin, G.H.; Pagès, L. Exploring root developmental plasticity to nitrogen with a three-dimensional architectural model. Plant Soil 2014, 385, 49-62. [CrossRef]

56. Linkohr, B.I.; Williamson, L.C.; Fitter, A.H.; Leyser, H.O. Nitrate and phosphate availability and distribution have different effects on root system architecture of Arabidopsis. Plant J. 2002, 29, 751-760. [CrossRef] [PubMed]

57. Krouk, G.; Lacombe, B.; Bielach, A.; Perrine-Walker, F.; Malinska, K.; Mounier, E.; Hoyerova, K.; Tillard, P.; Leon, S.; Ljung, K. Nitrate-regulated auxin transport by nrt1.1 defines a mechanism for nutrient sensing in plants. Dev. Cell 2010, 18, 927-937. [CrossRef] [PubMed]

58. Birouste, M.; Zamora-Ledezma, E.; Bossard, C.; Pérez-Ramos, I.M.; Roumet, C. Measurement of fine root tissue density: A comparison of three methods reveals the potential of root dry matter content. Plant Soil 2014, 374, 299-313. [CrossRef]

59. Rewald, B.; Rechenmacher, A.; Godbold, D.L. It's complicated: Intraroot system variability of respiration and morphological traits in four deciduous tree species. Plant Physiol. 2014, 166, 736-745. [CrossRef] [PubMed]

60. Irène, H.; Denis, V.; Cyrille, V.; Jeremy, D.; Beno?T, R.; Alain, B.; Eric, G.; Catherine, R. Relating root structure and anatomy to whole-plant functioning in 14 herbaceous mediterranean species. New Phytol. 2010, 173, 313-321.

61. Mccormack, M.L;; Guo, D. Impacts of environmental factors on fine root lifespan. Front. Plant Sci. 2014, 5, 205. [CrossRef]

62. Mooney, K.A.; Rayko, H.; Andre, K.; Agrawal, A.A. Evolutionary trade-offs in plants mediate the strength of trophic cascades. Science 2010, 327, 1642-1644. [CrossRef]

63. Hodge, A. The plastic plant: Root responses to heterogeneous supplies of nutrients. New Phytol. 2004, 162, 9-24. [CrossRef]

64. Hoch, G.; Richter, A.; Körner, C. Non-structural carbon compounds in temperate forest trees. Plant Cell Environ. 2003, 26, 1067-1081. [CrossRef]

65. Gaul, D.; Hertel, D.; Borken, W.; Matzner, E.; Leuschner, C. Effects of experimental drought on the fine root system of mature norway spruce. For. Ecol. Manag. 2008, 256, 1151-1159. [CrossRef]

66. Mcdowell, N.G. Mechanisms linking drought, hydraulics, carbon metabolism, and vegetation mortality. Plant Physiol. 2011, 155, 1051-1059. [CrossRef]

67. Zang, U.; Goisser, M.; Häberle, K.; Matyssek, R.; Borken, W. Effects of drought stress on photosynthesis, rhizosphere respiration, and fine-root characteristics of beech saplings: A rhizotron field study. J. Plant Nutr. Soil Sci. 2014, 177, 168-177. [CrossRef]

68. Galvez, D.A.; Landhäusser, S.M.; Tyree, M.T. Root carbon reserve dynamics in aspen seedlings: Does simulated drought induce reserve limitation? Tree Physiol. 2011, 31, 250-257. [CrossRef]

69. Henrik, H.; Waldemar, Z.; Olaf, K.; Susan, T. Thirst beats hunger-Declining hydration during drought prevents carbon starvation in norway spruce saplings. New Phytol. 2013, 200, 340-349. 
70. Gu, J.; Yu, S.; Sun, Y.; Wang, Z.; Guo, D. Influence of root structure on root survivorship: An analysis of 18 tree species using a minirhizotron method. Ecol. Res. 2011, 26, 755-762. [CrossRef]

71. Eissenstat, D.M.; Achor, D.S. Anatomical characteristics of roots of citrus rootstocks that vary in specific root lenght. New Phytol. 1999, 141, 309-321. [CrossRef]

72. Wahl, S.; Ryser, P. Root tissue structure is linked to ecological strategies of grasses. New Phytol. 2010, 148, 459-471. [CrossRef]

73. Fort, F.; Cruz, P.; Catrice, O.; Delbrut, A.; Luzarreta, M.; Stroia, C.; Jouany, C. Root functional trait syndromes and plasticity drive the ability of grassland fabaceae to tolerate water and phosphorus shortage. Environ. Exp. Bot. 2015, 110, 62-72. [CrossRef]

74. Padilla, F.M.; Aarts, B.H.J.; Roijendijk, Y.O.A.; Caluwe, H.D.; Mommer, L.; Visser, E.J.W.; Kroon, H.D. Root plasticity maintains growth of temperate grassland species under pulsed water supply. Plant Soil 2013, 369, 377-386. [CrossRef]

75. Hernández, E.I.; Vilagrosa, A.; Pausas, J.G.; Bellot, J. Morphological traits and water use strategies in seedlings of mediterranean coexisting species. Plant Ecol. 2010, 207, 233-244. [CrossRef]

76. Mccormack, M.; Adams, T.S.; Smithwick, E.A.H.; Eissenstat, D.M. Predicting fine root lifespan from plant functional traits in temperate trees. New Phytol. 2012, 195, 823-831. [CrossRef] [PubMed]

77. Markesteijn, L.; Poorter, L. Seedling root morphology and biomass allocation of 62 tropical tree species in relation to drought- and shade-tolerance. J. Ecol. 2009, 97, 311-325. [CrossRef]

78. Sun, Y.; Gu, J.; Zhuang, H.; Guo, D.; Wang, Z. Lower order roots more palatable to herbivores: A case study with two temperate tree species. Plant Soil 2011, 347, 351-361. [CrossRef]

79. Guo, D.L.; Mitchell, R.J.; Hendricks, J.J. Fine root branch orders respond differentially to carbon source-sink manipulations in a longleaf pine forest. Oecologia 2004, 140, 450-457. [CrossRef]

80. Comas, L.H.; Eissenstat, D.M. Patterns in root trait variation among 25 co-existing north american forest species. New Phytol. 2010, 182, 919-928. [CrossRef]

81. Eissenstat, D.M.; Kucharski, J.M.; Zadworny, M.; Adams, T.S.; Koide, R.T. Linking root traits to nutrient foraging in arbuscular mycorrhizal trees in a temperate forest. New Phytol. 2015, 208, 114-124. [CrossRef]

82. Holdaway, R.J.; Coomes, D.A. Species- and community-level patterns in fine root traits along a 120 000-year soil chronosequence in temperate rain forest. J Ecol. 2011, 99, 954-963. [CrossRef]

83. Chen, W.; Zeng, H.; Eissenstat, D.M.; Guo, D.L. Variation of first-order root traits across climatic gradients and evolutionary trends in geological time. Glob. Ecol. Biogeogr. 2013, 22, 846-856. [CrossRef]

84. Kong, D.L.; Ma, C.E.; Zhang, Q.; Li, L.; Chen, X.Y.; Zeng, H.; Guo, D.L. Leading dimensions in absorptive root trait variation across 96 subtropical forest species. New Phytol. 2014, 203, 863-872. [CrossRef] [PubMed]

85. Liu, B.T.; Li, H.B.; Zhu, B.; Koide, R.T.; Eissenstat, D.M.; Guo, D.L. Complementarity in nutrient foraging strategies of absorptive fine roots and arbuscular mycorrhizal fungi across 14 coexisting subtropical tree species. New Phytol. 2015, 208, 125-136. [CrossRef] [PubMed]

86. Makita, N.; Hirano, Y.; Dannoura, M.; Kominami, Y.; Mizoguchi, T.; Ishii, H.; Kanazawa, Y. Fine root morphological traits determine variation in root respiration of quercus serrata. Tree Physiol. 2009, 29, 579-585. [CrossRef]

87. George, K.; Norby, R.J.; Hamilton, J.G.; Delucia, E.H. Fine-root respiration in a loblolly pine and sweetgum forest growing in elevated co2. New Phytol. 2003, 160, 511-522. [CrossRef]

88. Xu, X.; Kuzyakov, Y.; Wanek, W.; Richter, A. Root-derived respiration and non-structural carbon of rice seedlings. Eur. J. Soil. Biol. 2008, 44, 22-29. [CrossRef]

89. Desrochers, A.; Landhäusser, S.M.; Lieffers, V.J. Coarse and fine root respiration in aspen (Populus tremuloides). Tree Physiol. 2002, 22, 725. [CrossRef] [PubMed]

90. Chen, D.; Zhou, L.; Rao, X.; Lin, Y.; Fu, S. Effects of root diameter and root nitrogen concentration on in situ root respiration among different seasons and tree species. Ecol. Res. 2010, 25, 983-993. [CrossRef]

91. Burton, A.J.; Jarvey, J.C.; Jarvi, M.P.; Zak, D.R.; Pregitzer, K.S. Chronic n deposition alters root respiration-tissue $\mathrm{n}$ relationship in northern hardwood forests. Glob. Chang. Biol. 2015, 18, 258-266. [CrossRef]

92. Wells, C.E.; Eissenstat, D.M. Beyond the roots of young seedlings: The influence of age and order on fine root physiology. J. Plant Growth Regul. 2002, 21, 324-334. [CrossRef]

(C) 2020 by the authors. Licensee MDPI, Basel, Switzerland. This article is an open access article distributed under the terms and conditions of the Creative Commons Attribution (CC BY) license (http://creativecommons.org/licenses/by/4.0/). 